\title{
Kasvatustieteellisiä näkökulmia työhön
}

Esa Poikela (toim.) ( 2005). Osaaminen ja kokemus - työ, oppiminen ja kasvatus. Tampere University Press.

Esa Poikelan toimittama kirja koostuu kolmestatoista artikkelista ja se on omistettu professori Annikki Järviselle. Kirja antaa hyvän kuvan Annikki Järvisen monista mielenkiinnon kohteista ja hänen laaja-alaisesta asiantuntijuudestaan. Vaikka artikkeleita on lukuisia, muodostuu kirjasta hyvä kokonaisuus, jossa työtä tarkastellaan kasvatustieteellisestä näkökulmasta. Kirjaa voikin suositella henkilöille, jotka haluavat kokonaiskuvan kasvatustieteilijöiden näkökulmista työelämään. Sen sijaan henkilö, joka on perehtynyt näihin näkökulmiin jo ennestään, saattaa kokea kirjassa toistettavan jo tutuiksi tulleita asioita.

Kirja alkaa lupaavasti Esa Poikelan artikkelilla työssä oppimisesta. Tämän teeman käsittely jatkuu ensimmäisessä luvussa, jossa on neljä artikkelissa. Työssä oppimisen tarkastelusta tuleekin keskeinen osa kirjan sisältöä. Kaikkiaan teeman käsittelylle on annettu noin 100 sivua kaikkiaan 280-sivuisessa kirjassa. Tämän osan kiinnostavinta antia ovat toisaalta Sari Poikelan pohdinta siitä, kuinka tutorina toimiminen on jatkuvaa työssä oppimista ja toisaalta eri artikkeleissa olevat käytännön esimerkit.

Kirjan toisessa luvussa käsitellään työn uudelleensuunnittelua, yritysten innovaatiokyvyn kehittämistä ja yrittäjyyskasvatusta. Luvussa olevat artikkelit (3 kpl) ovat sinänsä mielenkiintoisia, mutta niiden muodostama kokonaisuus ei oikein hahmotu. Työn muotoiluun liittyvä artikkeli on hyvä yhteenveto aiheesta. Yrityksen innovaatiokyvyn kehittämistä käsittelevän artikkelin lopussa esitetty väittämä, että kehittämisorganisaatio toimii virallisen ja epävirallisen organisaation välissä, on kiinnostava ja olisi ansainnut nykyistä suuremman tilan tekstissä. Yrittäjyyskasvatusta käsittelevä Paula Kyrön artikkeli ansaitsee paikkansa korkeatasoisena alan yhteenvetona.

Kolmas luku pureutuu työn ja oppimisen välisen suhteen tarkasteluun. David Boudin artikkeli tarjoaa tärkeän näkökulman siihen, kuinka työn ja oppimisen suhde on laajassa perspektiivissä muuttunut. Boudin toteaa muun muassa, että vaikka jälkimodernistisessa yhteiskunnassa työn ja oppimisen suhde näyttää pirstaleiselta, on käynnissä työn ja oppimisen välinen uusintegraatio. Tämän prosessin seurauksena työstä on tulemassa oppimista ja oppimisesta on tulossa työtä. Samassa luvussa Pekka Ruohotie tarkastelee kiinnostavalla tavalla uudenlaisia uria ja elinikäistä ammatillista kasvua. Ruohotien esittämän näkökulmat reflektiosta ansaitsevat erityismaininnan.

Neljäs luku käsittelee kokemusta, kulttuurien kohtaamista ja kielikasvatusta. Myös tämä luku jää hajanaiseksi. Luvun aloittaa Pauli Kaikkosen artikkeli, jossa viitataan kiinnostavasti kulttuurien kohtaamiseen ja monikulttuurisuuden teemaan yleisemminkin. Artikkeli antaa uudenlaisia näkökulmia kulttuurienväliseen oppimiseen. Erityisen avartava oli havainto, että "vasta konfliktit mahdollistivat syvälle ankkuroituneen kulttuurisen käyttäytymisen käsittelyn ja johtivat sitä kautta kulttuurien väliseen oppimiseen”. Artikkelissa painotettu kulttuurien välisille eroille herkistyminen ja se, että opettaja on kulttuurienvälisen oppimisen prosessien käynnistäjä, ovat kiinnostavia havaintoja monikulttuurisuuskasvatuksesta.

Vaikka kirjassa on monia hyviä artikkeleja, löytyy myös melko irrallisiksi jääviä artikkeleja. Esimerkiksi viimeisenä esitetty artikkeli eurooppalaisesta kielisalkusta kielikasvatuksen välineenä antanee lisäarvoa vain aiheesta kiinnostuneille.

Kaikkiaan kirja on suositeltavaa lukemista aikuiskasvatusta sekä työn ja kasvatuksen välisiä yhteyksiä pohtiville henkilöille. Vaikka kirja suurelta osalta kertaakin jo tiedettyä, voi kokenutkin aiheen tarkastelija poimia tekstin lomasta itselleen arvokkaita idean poikasia.

PAULI JUUTI 